\title{
Effects of a 10\% Carbamide Peroxide Bleaching Agent on Rat Oral Epithelium Proliferation
}

\author{
Rodrigo de Castro ALBUQUERQUE ${ }^{1}$ \\ Ricardo Santiago GOMEZ ${ }^{2}$ \\ Rodrigo Aliprandi DUTRA ${ }^{1}$ \\ Wallison Arthuso VASCONCELLOS ${ }^{1}$ \\ Renato Santiago GOMEZ ${ }^{3}$ \\ Marcus Vinícius GOMEZ ${ }^{4}$ \\ ${ }^{1}$ Department of Restorative Dentistry, School of Dentistry \\ ${ }^{2}$ Department of Oral Surgery and Pathology, School of Dentistry \\ ${ }^{3}$ Department of Surgery, School of Medicine \\ ${ }^{4}$ Department of Pharmacology, Institute of Biological Sciences \\ Federal University of Minas Gerais, Belo Horizonte, MG, Brazil
}

\begin{abstract}
The purpose of the present study was to evaluate the influence of short course topical application of carbamide peroxide on proliferating cell nuclear antigen (PCNA) immunohistochemical expression in the oral tongue mucosa of rats. Twelve male Wistar rats were submitted to topical application of $10 \%$ carbamide peroxide on one side of the dorsal tongue once a week for three consecutive weeks. Only distilled water was applied on the control side. The animals were killed on days 0,10 , and 20 after the last application. The tongue was fixed in buffered formalin for $24 \mathrm{~h}$ and embedded in paraffin. Tissue blocks $(3 \mu \mathrm{m})$ were subjected to the biotin-streptavidin amplified system for identification of PCNA. The percentage of epithelial-positive basal cells in each side of the tongue mucosa was calculated. The results demonstrated that topical application of $10 \%$ carbamide peroxide increases PCNA immunohistochemical expression on the basal layer of the oral mucosa epithelium of rats on day 0 after treatment. In conclusion, short-course use of carbamide peroxide induces transient epithelial cell proliferation of the oral mucosa of rats.
\end{abstract}

Key Words: carbamide peroxide, immunocytochemistry, oral mucosa, proliferating cell nuclear antigen, carcinogenesis.

\section{INTRODUCTION}

Bleaching of vital teeth is becoming a more commonly used treatment in the dental office. Some years ago, a technique for bleaching vital teeth involving the topical application of $10 \%$ carbamide peroxide was introduced (1). Significant controversy has been generated regarding the risk of tissue damage from contact of the agent with the oral mucosa (2-7).

The proliferating cell nuclear antigen (PCNA), an auxiliary protein of DNA polymerase delta, is considered to be related to cell proliferation (8). This protein has been shown to fluctuate during the cell cycle and to increase in late $\mathrm{G}_{1}$ and $\mathrm{S}$ phases. Some studies have proposed that PCNA immunohistochemi- cal expression can be used to provide information regarding tumor differentiation, proliferation, and prognosis (9-11).

Concerns about the safety of the chronic use of carbamide peroxides on oral mucosa still exist in the literature (2-7). Although some studies have addressed the carcinogenic or cocarcinogenic activity of bleaching agents $(7,12)$, the long protocol used by the authors to assess the results makes the extrapolation to at-home tooth bleaching treatments difficult. Therefore, the purpose of the present study was to evaluate oral epithelial cell proliferation in rats after short course application of $10 \%$ carbamide peroxide. The epithelial cell proliferation index was estimated by the immunohistochemical expression of PCNA.

Correspondence: Dr. Ricardo Santiago Gomez, Departamento de Clínica, Patologia e Cirurgia, Faculdade de Odontologia, Universidade Federal de Minas Gerais, Avenida Antônio Carlos 6627, 31270-901 Belo Horizonte, MG, Brasil. Tel: +55-31-3499-2477. Fax: +55-31-3499-2472. E-mail: rsgomez@net.em.com.br 


\section{MATERIAL AND METHODS}

Twelve male Wistar rats weighing 190 to $255 \mathrm{~g}$ were used in the experiments. The animals were allowed free access to standard pellet chow and water. At the time of the study there were no clinical signs of disease in any animal. The rats were anesthetized with an intraperitoneal injection mixture of ketamine (72 $\mathrm{mg} / \mathrm{kg}$ body weight, Ketalar, Parke-Davis, Itapira, SP, Brazil) and xylazine $(11 \mathrm{mg} / \mathrm{kg}$ body weight, Rompun, Bayer, São Paulo, SP, Brazil) as previously described (13). Intraperitoneal injections were given with animals in dorsal recumbence and they were allowed to recover on a $38 \times 28 \mathrm{~cm}$ dry base pad in a warm draught-free room. About $200 \mathrm{mg}$ of $10 \%$ carbamide peroxide (Opalescence, Ultradent Products, South Jordan, UT, USA) was applied on one side of the dorsal tongue for $20 \mathrm{~min}$. The tongue surface was washed with distilled water before and after this procedure. Only distilled water was applied on the control side. During the experiments no spread of the bleaching agent around the mouth was observed. The procedures were done once a week for three consecutive weeks. Groups of 4 animals were killed on days 0,10 , and 20 after the last treatment. Day 0 was immediately after the last treatment. The tongue was removed, cut sagitally, fixed in $10 \%$ buffered formalin for $24 \mathrm{~h}$ and embedded in paraffin.

\section{Immunohistochemical Methods}

Tissue blocks were cut at $3 \mu \mathrm{m}$ and subjected to the biotin-streptavidin amplified system. To improve PCNA immunohistochemical expression, microwave

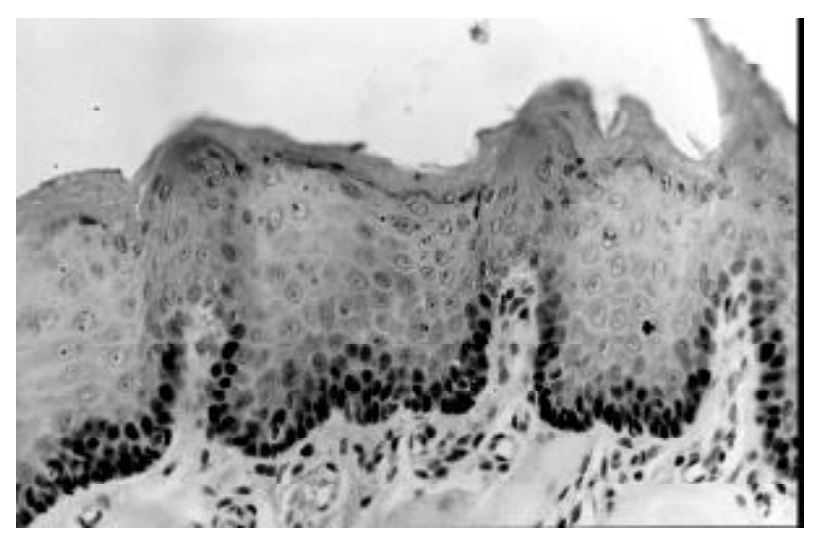

Figure 1. PCNA expression in basal and parabasal cells on the tongue mucosa of rats (streptavidin-biotin-peroxidase complex stain, original magnification $400 \mathrm{X})$. stimulation was carried out as described by Shi et al. (14). The sections were submitted to a microwave in a citrate buffer pre-treatment $(\mathrm{pH} 6.0,10 \mathrm{mM})$ for 15 $\mathrm{min}$. The samples were then immersed in $3 \%$ methanolhydrogen peroxide solution for $10 \mathrm{~min}$ to block endogenous peroxidase activity, washed in tris- $\mathrm{HCl}$ buffer ( $\mathrm{pH}$ 7.4) and incubated with anti-PCNA (Clone PC10, 1:3000 Sigma, St. Louis, MO, USA) in $5 \mathrm{mM}$ tris- $\mathrm{HCl}$ buffer for $18 \mathrm{~h}$ at $4^{\circ} \mathrm{C}$. After washing in tris$\mathrm{HCl}$ buffer ( $\mathrm{pH} 7.4)$, the sections were incubated at room temperature with 1) biotinylated swine anti-goat, mouse and rabbit immunoglobulin (DAKO, Carpinteria, CA, USA) diluted 1:150 in tris- $\mathrm{HCl}$ for 30 minutes; 2) washed with tris- $\mathrm{HCl}$ twice for $10 \mathrm{~min}$; 3) incubated for $30 \mathrm{~min}$ with horseradish peroxidase-conjugated streptavidin (DAKO) prepared according to the manufacturer instructions; 4) washed with tris- $\mathrm{HCl}$; 5) incubated for $3 \mathrm{~min}$ with $0.01 \%$ diamine benzidine tetrahydrochloride (DAB) and $0.03 \% \mathrm{H}_{2} \mathrm{O}_{2}$ in $5 \mathrm{mM}$ tris- $\mathrm{HCl}$ buffer ( $\mathrm{pH} 7.4) ; 6)$ rinsed in distilled $\mathrm{H}_{2} \mathrm{O}$ for $10 \mathrm{~min}$ and counterstained with Mayer's hematoxylin. To avoid false positive results, a series of tissue sections were stained with omission of the primary antibody or using adsorbed primary antibody with purified PCNA protein (25 ng PCNA per ml of anti-PCNA antibody diluted 1:3000 tris- $\mathrm{HCl}$ ). Oral squamous cell carcinoma tissues were used as positive controls.

\section{Cell Quantification and Statistical Analysis}

The expression of PCNA was quantitatively analyzed. Epithelial cells were considered to be positive if there was any staining of the nucleus, regardless of staining intensity. Six high-power microscopic fields (400X) were selected in each side of the dorsal tongue (experimental and control). Since PCNA is mainly expressed at the basal layer of the epithelium, it was calculated by the percentage of immunopositive basal cells. The total number of basal cells along the six microscopic fields and the number of basal cells stained were assessed. As the control and experimental specimens were obtained simultaneously from the tongue of the same animal and percentage does not conform to normal distribution, the Wilcoxon signed rank test was used for statistical analysis. The values were considered significantly different when the $\mathrm{p}$ value was less than 0.05 . 


\section{RESULTS}

PCNA staining was mainly observed on the basal layer of the tongue mucosa (Figure 1). The percentage of positive basal cells on the treated and on the nontreated side of the epithelium of the dorsal tongue on days 0,10 and 20 is shown in Figure 2. The mean percentage of PCNA immunostaining on the side treated with carbamide peroxide was greater than on the control side of the mucosa on day 0 after the last application $(\mathrm{p}=0.0053)$. On days 10 and 20 , no difference was observed between the experimental and control side of the mucosa.

\section{DISCUSSION}

Although non-cycling cells may express PCNA immunoreactivity - possibly due to increased PCNAmRNA stability induced by growth factor (15) - it is used as an indicator of cellular proliferation (9-11). Our results showed that topical application of carbamide peroxide increased transitorily PCNA expression on the basal layer of the oral mucosa epithelium of rats. This finding partly explains those reported by Weitzman et al. (16), who studied the effects of twice weekly topical application of $30 \%$ hydrogen peroxide and/or DMBA on the buccal epithelium of Syrian hamsters. They observed that the buccal mucosa of all animals treated with peroxide hydrogen alone showed hyperkeratosis and hyperplasia. Although no clinical evidence of mucosa alterations was detected in our study, the present data suggested increased epithelium turnover induced by short-course application of carbamide peroxide.

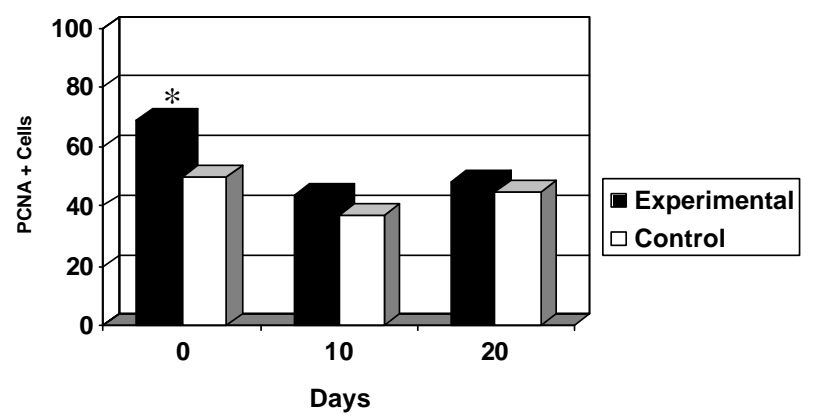

Figure 2. Mean percentage of PCNA immunopositive basal cells on the tongue mucosa at 0,10 and 20 days after topical application of $10 \%$ carbamide peroxide once a week for 3 consecutive weeks. $* \mathrm{p}=0.0053$ (Wilcoxon signed rank test).
The carcinogenic potentiality of bleaching agents is controversial. Hyperchromatic cells and mild dysplasia induced by bleaching agents is reported in the oral mucosa of experimental animals (16). On the other hand, additional studies did not confirm that hydrogen peroxide is carcinogenic or cocarcinogenic (12). In the present study, the carcinogenic activity of carbamide peroxide was not directly investigated. The short-course protocol of treatment did not induce any cytological atypia. Futhermore, increased PCNA expression in the experimental side of the mucosa was observed only on day 0 . On days 10 and 20 after the last application, no difference was noted between the experimental and control groups (Figure 2). Probably in order for PCNA to be continuously expressed in the experimental side of the oral mucosa, continuous application of carbamide peroxide would have to be carried out until the cells became completely autonomous.

It is well known that carcinogenesis is a multistep process that involves chromosomal instability in transformed cells. Even considering relevant the transitory cellular proliferation induced by carbamide peroxide, this event constitutes only one of these multiple steps. Since some chemical irritants might produce similar results, the present finding does not necessarily indicate tumor initiation. Futhermore, the hypothesis that topical use of carbamide peroxide could augment carcinogenesis associated with other carcinogens must be evaluated in additional studies using long-course application of this agent. Although there is no reliable specific marker for early carcinogenesis transformation, it would be interesting in the future to evaluate the effects of carbamide peroxide on some oncogenes (MDM2) and tumor suppressor genes (p53, PTCH) regulation.

In conclusion, our findings show that shortcourse use of carbamide peroxide increases transitorily epithelial cell proliferation of rat oral mucosa. Further immunohistochemical and molecular investigations are necessary to elucidate the influence of bleaching agents on cell cycle regulation and cancer development.

\section{ACKNOWLEDGMENTS}

This study was supported by Conselho Nacional de Desenvolvimento Científico e Tecnológico (CNPq), Fundação de Amparo à Pesquisa do Estado de Minas Gerais (FAPEMIG) and PRONEX. Drs. R.S. Gomez 
and M.V. Gomez are research fellows of CNPq.

\section{RESUMO}

Albuquerque RC, Gomez RS, Dutra RA, Vasconcellos WA, Gomez RS, Gomez MV. Efeito do agente clareador contendo peróxido de carbamida a $10 \%$ na proliferação do epitélio oral de ratos. Braz Dent J 2002;13(3):162-165.

O propósito do presente estudo foi avaliar a influência da aplicação tópica de peróxido de carbamida na expressão imunohistoquímica do antígeno nuclear de proliferação celular (PCNA) na mucosa oral da língua de ratos. Doze ratos Wistar machos foram selecionados e submetidos a aplicação tópica de peróxido de carbamida a 10\% sobre um lado do dorso da língua. O tratamento foi feito uma vez por semana por três semanas consecutivas. Água destilada foi aplicada no lado controle. Os animais foram sacrificados nos dias 0,10 , e 20 depois da última aplicação. A língua foi fixada em tampão de formalina por 24 horas e embebido em parafina. Cortes de tecido de $3 \mu \mathrm{m}$ foram submetidos ao sistema de amplificação streptavidina-biotina para identificação do PCNA. A porcentagem de células basais epiteliais positivas em cada lado da mucosa da lingua foi calculada (experimental e controle). O resultado demonstrou que a aplicação tópica de peróxido de carbamida a $10 \%$ aumenta a expressão imunohistoquímica do PCNA na camada basal do epitélio da mucosa oral de ratos no dia 0 depois do tratamento. Concluiu-se que a uso em curto período de peróxido de carbamida a $10 \%$ induz proliferação celular epitelial transitória da mucosa oral de ratos.

Unitermos: peróxido de carbamida, imunohistoquímica, mucosa oral, antígeno nuclear de proliferação celular, carcinogênese.

\section{REFERENCES}

1. Haywood VB, Heymann HO. Nightguard vital bleaching. Quintessence Int 1989;20:173-176.
2. Woolverton CJ, Haywood VB, Heymann HO. Toxicity of two carbamide peroxide products used in nightguard vital bleaching. Am J Dent 1993;6:310-314.

3. Curtis JW, Dickinson GL, Downey MC. Assessing the effects of 10 percent carbamide peroxide on oral soft tissues. J Am Dent Assoc 1996;127:1218-1223.

4. Rosenstiel SF, Gagauff AG, Johnston WM. Randomized clinical trial of the efficacy and safety of a home bleaching procedure. Quintessence Int 1996;27:413-424.

5. Floyd RA. The effect of peroxides and free radicals on body tissues. J Am Dent Assoc 1997; 128:37S-40S.

6. Ly Y. Tooth bleaching using peroxide-containing agents: Current status of safety issues. Compedium 1998;19:783-794.

7. Pieroli DA, Navarro, MFL, Consolaro A. Evaluation of the carcinogenic potential of bleaching agents in a DMBA inductionmodel. Oral Med Pathol 2000;5:29-34.

8. Bravo R, Frank R, Blundell PA, MacDonald-Bravo H. Cyclin/ PCNA is the auxiliary protein of polymerase. Nature 1987;326:515-517.

9. Coltrera MD, Zarbo RJ, Sakr WA, Gown AM. Markers for dysplasia of the upper aerodigestive tract. Suprabasal expression of PCNA, p53 and CK 19 in alcohol-fixed, embedded tissue. Am J Pathol 1992;141:817-825.

10. McCormick D, Hall PA. The complexities of proliferating cell nuclear antigen. Histopathol 1992;21:591-594.

11. Huang WYF, Coltrera M, Shubert M, Morton T, Truelov E. Histopathologic evaluation of proliferating cell nuclear antigen (PC10) in oral epithelial hyperplasias and premalignant lesions. Oral Surg Oral Med Oral Pathol 1994;78:748-754.

12. Marshall MV, Kuhn JO, Torrey CF. Hamster cheek pouch biossay of dentrifice containing hydrogen peroxide and baking soda. J Am Coll Toxicol 1996;15:45-61.

13. Smith W. Responses of laboratory animals to some injectable anaesthetics. Laboratory Animals 1993;27:30-39.

14. Shi SR, Cote RJ, Taylor CR. Antigen retrieval in immunohistochemistry: Past, present, and future. J Histochem Cytochem 1997;45:327-343.

15. Mighell A. PCNA and p53. Oral Oncol Eur J Cancer 1995;31B:403-404

16. Weitzman AS, Weitberg AB, Stossel TP, Schwartz J, Shklar G. Effects of hydrogen peroxide on oral carcinogenesis in hamsters. J Periodontol 1986;57:685-688.

Accepted April 24, 2002 